\title{
Educational building conditions and the health of users
}

\author{
Abiodun Olatunji Abisuga ${ }^{1}$, Ibukun O. Famakin ${ }^{2}$, Olalekan S. Oshodi ${ }^{2}$ \\ ${ }^{1}$ Faculty of the Built Environment, The University. of New South Wales, Australia \\ ${ }^{2}$ Department of Architecture and Civil Engineering, City University of Hong Kong
}

\begin{abstract}
In order to maintain a healthy learning environment, diagnosis and management of defects in the educational facility are paramount. The preliminary results of the ongoing research reported here seek to identify defects associated with educational buildings and their effects on the health of polytechnic students and staff in Nigeria. A questionnaire survey, including 34 defects based on a post-occupancy evaluation (POE) was used to establish relationships with the health of polytechnic students and staff. Two hundred (200) respondents were randomly selected based on their schools (faculty) within Lagos State Polytechnic. Descriptive and inferential statistics were used for analysis of the collected data. The results of the study indicate that defects such as plumbing and dampness problems, cobwebs and dust, are prominent in the institution. Also the relationship between building conditions (defects) and health problems was established, with the predictors of the health problems. Based on the findings, it is important for designers and managers of facilities within tertiary institutions to develop and implement design and maintenance policies targeted at minimizing the likelihood of plumbing, dampness, electrical, cobweb and dust problems in educational buildings due to the health risks induced by the defects. It is evident that effective maintenance schedules and policies should be put in place to ensure that facilities are not left to decay before replacement.
\end{abstract}

Keywords: Building defects, educational buildings, facilities, health, maintenance, Nigeria.

Paper type - Research article

\section{Introduction}

Education provides the knowledge and skills required for human capital development in any nation. In Nigeria, polytechnics are mandated by law to train middle-level technical employees. Studies have demonstrated that the quality of school facilities plays a crucial role in student's academic performance, learning effectiveness and behaviour (Leung and Fung, 2005; Tanner, 2009). It is suggested that effective management of facilities within schools play a vital role in achieving the targeted goal of polytechnics.

Learning and other academic activities take place in an indoor environment. Building services (such as lighting, air conditioning, etc.) are provided in learning spaces so as to improve comfort, health and safety of the occupants, and facilitate the learning process between the teacher's and the students. Empirical evidence from previous studies has shown that the quality of building facilities

\footnotetext{
Copyright: Construction Economics and Building 2016. (C) 2016 Abiodun Olatunji Abisuga, Ibukun O. Famakin, Olalekan S. Oshodi. This is an Open Access article distributed under the terms of the Creative Commons Attribution 4.0 Unported (CC BY 4.0) License (https://creativecommons.org/licenses/by/4.0/), allowing third parties to copy and redistribute the material in any medium or format and to remix, transform, and build upon the material for any purpose, even commercially, provided the original work is properly cited and states its license.
}

Citation: Abisuga A. O., Famakin, I. O. and Oshodi S. O. 2016. Educational building conditions and the health of users. Construction Economics and Building, 16(4), 19-34. DOI: http://dx.doi.org/10.5130/AJCEB.v16i4.4979

Corresponding author: Abiodun Olatunji Abisuga; Email - o.abisuga@student.unsw.edu.au

Publisher: University of Technology Sydney (UTS) ePress 
has a significant influence on staff and students' comfort, satisfaction and the school image (Kok et al., 2011; Leung and Fung, 2005; Uline and Tschannen-Moran, 2008). Similarly Simpeh (2013) acknowledges that lighting, ventilation, cleanliness, structural safety, temperature, sound control, fire safety and aesthetics were parameters whose failure affects health and safety in an academic environment. Hence, it is evident that educational buildings and associated facilities have a significant impact on occupants.

Defects are viewed as deficiencies in the function, performance, and requirements of a building (Low and Darren, 2001). Defects in poorly maintained indoor environments have been linked to building related illnesses experienced by users. Building related illness such as headaches, skin irritation, memory loss, loss of concentration, blood pressure, pulse, brain activity, biorhythms and watering eyes/nose have been reported in several studies (Claudio et al., 2016; Gou and Lau, 2012; Tanner, 2000; Vafaeenasah et al., 2015; Wong and Jan, 2003). Putus (2012) and Agyekum et al. (2013) have associated health problems experienced in buildings with low functionality of building facilities. Defects reduce the efficiency and performance of indoor spaces in academic buildings.

Previously, researchers have studied user satisfaction with educational facilities using a post occupancy evaluation (Adewumi et al., 2011; McGrath and Horton, 2011; Sawyerr and Yusof, 2013), performance of educational buildings (Hassanain, 2008; Wong and Jan, 2003), defects in educational buildings (Olanrewaju 2012; Wahab and Hamid, 2011), and effects of educational building facilities on academic performance of students (Leung and Fung, 2005; Uline and Tschannen-Moran, 2008). However, limited studies have investigated the relationship between defects in educational buildings and building related illnesses (physical, psychological and physiological) experienced by users. This study addresses the gap in the existing literature by investigating the relationships between educational building defects and the health of students and staff.

The remainder of the paper is divided into seven parts. The first section gives a brief overview of the case study polytechnic. The second section presents a review of literature related to the subject of this study. Third, the conceptual framework of the study is presented. In the research method section, the process of conducting research and selecting the sample is discussed. Descriptive and inferential statistics were used to analyse the valid questionnaires received. In the discussion section, the results of this study were compared with those of prior studies found in the literature. Finally, the summary of the findings, limitations, and areas for future research are also presented.

\section{Study context}

Lagos State Polytechnic is a State Government owned institution and currently operates from three campuses (Ikorodu, Isolo and Surulere). The institution was established by promulgation Lagos State Edict No. 1 of 1978, and on 1 August 1978. The Polytechnic operates five schools, namely: School of Management and Business Studies (SM \& BS), School of Engineering (SENG), School of Environmental Studies (SES), School of Agriculture (SOA), and School of Technology (SST). The institution has a staff of over 964 (academic and non-academic), a large student population, comprising 6,030 full-time students and 52 accredited programmes in 31 academic departments across the various schools. The Polytechnic awards two classes of degree: National Diploma (ND) and Higher National Diploma (HND).

Lagos State is in a hot tropical climate with high-relative humidity. This is an indication that buildings in the state are exposed to invariable weather conditions which consistently include rain, wind, and solar radiation, all significant contributors to building deterioration. The Polytechnic buildings are characterised by concrete frame structures, solid brick or sandcrete block walls, with 
cement and sand mortar bed joints. The doors are in timber joinery either flush or panel type, while the windows are in glass and aluminium, sliding or projected. The floors are mainly finished with PVC tiles, terrazzo and ceramic tiles on screeded bed. The sanitary appliances and fittings are ceramic wares connected with PVC pressure pipes. The walls of the sandcrete block structure are plastered and rendered in cement and sand, painted with emulsion paints (see Figure 1 and 2). The buildings are predominately roofed with asbestos or aluminium sheets. The average age of most of the buildings and facilities in the school is 15 years, except for the newly constructed buildings.

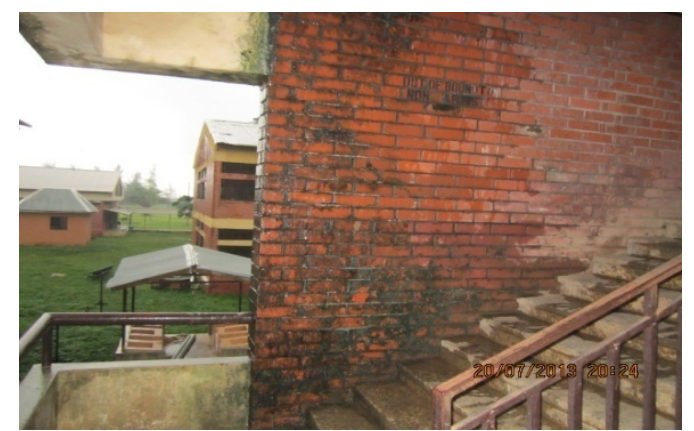

Figure1: Wall dampness during rainfall

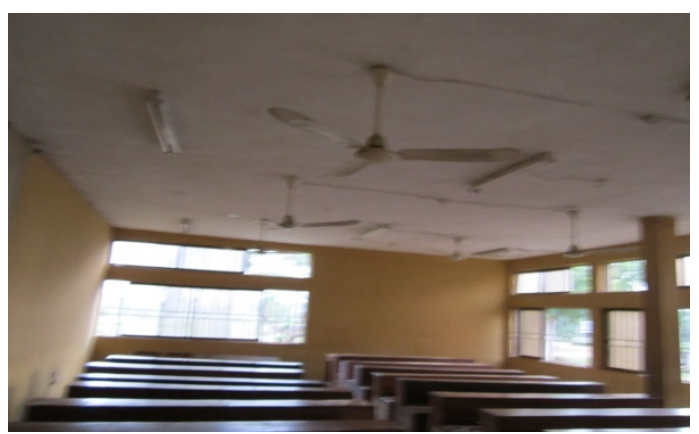

Figure 2: A typical classroom setting

\section{Literature review}

\section{Defects in building facilities}

Facilities and the condition of the indoor environment (e.g., lighting, climate control, indoor air quality, and acoustic control) have a significant impact on comfort and perceived satisfaction of staff and students (Kok et al,. 2011; Lavy, 2008; Uline and Tschannen-Moran, 2008). In the operational phase, facilities in a building are subject to wear and tear which erode its performance over time (Low and Darren, 2001). These facilities become defective if not adequately maintained. In the literature, several defects in buildings have been identified. The defects include: fungi growth, discolouration, waterproofing system, cracks in walls, roof leakages, soil settlement, rainwater penetration, leakage problems, corrosion of steel structure, faulty communication appliance, faulty doors and windows, roof damages, mechanical and electrical system faults (Forcada et al., 2015; Olanrenwaju, 2012; Wahab and Hamid, 2011; Wong and Jan, 2003). However, Olarenwaju (2012) acknowledged that the degree of impact of defective facilities on users' is dependent on the users' requirements in terms of safety, security, convenience and comfort. In addition, lack of maintenance and neglect causes defects in buildings which lead to water ingress and dampness. The dampness produces pathogenic toxic mould and other biological effects that induces sick building syndrome (SBS) in occupant's (Singh et al., 2010). Likewise, the misuse of facilities by occupant's due to inadequate knowledge of building use causes defects that affect a facilities performance (Gupta and Kapsali, 2016).

A building provides an indoor environment which is needed for human activities. Other researchers (Simpeh, 2013) have linked the functional state of lighting, ventilation, cleanliness, structural safety, temperature, sound control, fire safety and aesthetics with health and safety in a learning environment. Thus, it is imperative for administrators and managers of facilities in educational institutions to ensure that the buildings and its ancillary facilities perform optimally. 


\section{Sick building syndrome in educational buildings}

Sick building syndrome (SBS) refers to building related sickness experienced by occupants when in a building or a specific part of the building. Diverse building related sickness such as headache, tiredness, fatique, cough, itching and burning eyes, runny nose and their related causes have been identified in the literature (Claudio et al., 2016; Putus, 2012; Vafaeenasah et al., 2015; Wong and Jan, 2003). For example, Claudio, Rivera, and Ramirez (2016) found that dust was associated with colds, nasal congestion and sore throats, while carpets induce the risk of having asthma and itchy eyes. Also, the result of their study showed that respiratory infections, eye irritation, nasal congestion and sore throats were associated with damaged water system or mold. Vafaeenasah et al. (2015) conducted a survey on SBS in university teaching hospitals, the results indicate that most of the nurses experienced headaches, fatigue, dry hands, coughs, and burning eyes. Similarly, in a survey conducted in educational laboratories most of the students experienced all the SBS symptoms such as dry skin, runny noses, dry eyes, blocked/stuffy nose, tiredness and flu-like symptoms (Amina et al., 2015). In the same vein, Gupta, Khare and Goyal (2007) found headaches, lethargy and dryness in body mucous in air conditioned buildings. Also, there is a significant relationship between building characteristics, time spent on a computer, job stress and eye wear, and SBS (Gupta et al., 2007). In addition, there is a positive relationship between air humidity in classrooms and mucosal symptoms and general symptoms (Takaokai et al., 2016). Salleh et al (2016), discovered more absenteeism in air conditioned classrooms due to SBS. Female occupants are more prone to SBS than their male counterpart (Gupta, et al., 2007). Based on these attestations exposure to sick buildings can induce physical, physiological and psychological health problems on occupants of buildings.

\section{Post occupancy evaluation of educational buildings}

Existing research recognizes the critical role of post occupant evaluation (POE) techniques in assessing the conditions of the building. Often this method is based on the building user's perceptions (Adewumi et al., 2011; Gupta and Chandiwala, 2010; McGrath and Horton, 2011; Sawyerr and Yusof, 2013). This is necessary to identify the indicators of satisfaction of end user's in relation to the building fabrics and facilities. The interest in POE of educational buildings is growing. This could be linked to the influence of the condition of the learning environment on academic performance. Despite the importance of functional facilities in enhancing academic performance, educational institutions still experience reduced performance in facilities due to defects. Olanrewaju (2012) conducted a POE of universities buildings; 24 critical defects that affect security, safety and comfort of users were identified. The findings of Hassanain and Mudhei (2006) indicate the users were dissatisfied with flooring, furniture quality and quantity, proximity, privacy, quality and quantity of toilets, clarity of emergency exits, identification of library sections and the number of storeys. Adewunmi et al. (2011) indicate that deficiencies in internet facilities, space, interior design, communication systems, room temperature and fire safety are significant defects in educational buildings. Noise infiltration was also seen as a major deficiency in university precincts (McGrath and Horton, 2011; Adewunmi et al., 2011). Gallifa and Batalle (2010), conducted a survey of service quality in multi campuses in Spain. The results of the study show that the quality of services in the library and bar/restaurant have decreased over time due to lack of maintenance. In addition, little improvement was noted in signposting and facilities, causing deficiency in security and confidence. These facilities are parameters whose failure affects health and safety in an academic environment (Simpeh, 2013). Facilities failure is mostly caused by errors and deficiency in design, construction, and maintenance of buildings. Therefore, defective facilities must be identified by conducting frequent POE in educational buildings and necessary actions implemented to prevent facilities failure. 


\section{Overall health of building users}

The World Health Organization defined health as a complete state of physical, mental and social well-being, and not merely the absence of disease or infirmity. From the above definition of health it is evident that the well being of individuals is influenced by the living environment. Hasselaar (2009) points out that the indoor environment of buildings induces certain health hazards to occupants. These health risks are largely dependent on the quality and physical characteristics of the building (Hasselaar, 2009). Therefore, constructed spaces meant for educational uses should enhance physical, physiological and psychological health of students and staff members.

Physical health, which refers to individual perception of his/her physical condition, is relatively the absence of disease, its symptoms and the adverse effect of treatment (Gomez et al., 2010). It is the ability to perform daily activities required to meet basic self-care needs and reflected in the functional capacity, functional performance, muscle strength and social function (Chang and Tamura, 2009; Starfield, 2001). Physical health is a major component when defining quality of life of individuals irrespective of age, making it the most cited factor for measuring the quality of life (Cummings, 1997; Escuder-Mollon et al., 2012; Schalock and Verdugo, 2002). The importance of physical health is evident in the assertion that "health is wealth". A major factor influencing the functional ability and physical health of students and staff members in their living environment is the performance of facilities in the building (Gou and Lau, 2012; Sivam and Karuppannan, 2015).

Physiological health is the state of the interaction of human and their parts, including all mechanical, physical and biochemical processes. Some symptoms of poor physiological health include a cough, dizziness, cold, skin irritation, watering nose and eyes, which may be caused by poor indoor air quality of the academic environment (Wong and Jan, 2003). In addition, an overpopulated classroom with high humidity can also contribute to the spreading of germs and irritation that causes physiological problems (Wong and Jan, 2003). In a similar vein, Van Dijken, Van Bronswijk, and Sundell (2006) state that pollution due to a high concentration of particles and dust were major factors that affect students physiological feelings.

Psychological health refers to the affective or emotional status of an individual's inner experience which either makes him/her feel good, neutral or unhappy (Gomez et al., 2010). The quality of indoor air is associated with mental fatigue and poor concentration in educational buildings (Wong and Jan, 2003). For example, noise caused distractions and reduced the rate of concentration (Olanrewaju, 2012; Wong and Jan, 2003); lighting colour affects blood pressure, respiration rate and brain activity (Tanner, 2000) and damaged security and safety facilities causes fear in students (Olanrewaju, 2012). There is also an association between students psychosocial factors and indoor air quality, and the school psychosocial environment (Finell et al., 2016). Likewise, if an educational environment cannot give psychological comfort to students and staff, it can result in increased absenteeism, withdrawal behaviours, strain, loss of productivity, accidents and injuries.

\section{Conceptual framework}

Based on an extensive literature review presented above, the study hypothesizes that the defects in an educational building can influence the health of students and staff members. A conceptual model $(\mathrm{BD}-\mathrm{OH})$ is developed to explain the possible relationship and impact between building defects and the health of students and staff members in the Lagos State Polytechnic (see Figure 3).

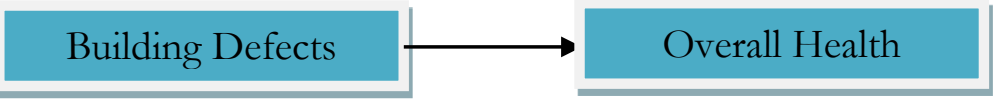

Figure 3: Conceptual model for building defects and overall health in educational buildings 


\section{Research method}

Building/facilities management is an increasingly important area in the field of construction management. This assertion is validated by the increasing number of publications found in literature (Falorca et al., 2014; Leung and Fung, 2005). To date, various methods have been applied in studies focused on facilities management/maintenance management problems. The methods found include: quantitative, case study, modeling, simulation and observation (Boussabaine and Kirkham, 2004; Chan and Hung, 2015; Chiang et al., 2014; Shohet and Paciuk, 2006). The suitability of a particular method to research problems has been an issue of growing academic debate in construction management. Al-Sehaimi, Koskela, and Tzortzopoulos (2013) suggested the need to apply action research methods in project performance as a good illustration. However, the choice and appropriateness of a particular research method is dependent on the research problem (Wing et al., 1998). The questionnaire survey research method provides a means for collecting quantitative data. This approach was adopted in this study because of the need to collect data from a large group of respondents, including the need to generalize and test hypothesis (Wing, et al., 1998; Thietart, 2001).

The study was conducted in three phases: first, a comprehensive review of existing literature was carried out to identify research on the impact of building defects on occupants health. Second, qualitative data were collected through participant (users) observations and interviews conducted among students and staff members to identify building defects and health challenges experienced when using the facilities provided for learning in the selected institution. This was done so as to ensure that the context of the selected institution was properly captured by the survey instrument developed at the next phase. A deductive and inductive approach was adopted to enrich existing literature, placing it in the context of the study area. From the qualitative study and physical observations of the school, 34 defects and 11 health challenges were identified which were used to prepare the questionnaire for the study. The questionnaire consisted of two sections, namely: (1) the degree of criticality of the defects; and (2) frequency of health symptoms. Numerical scores ranging from 1 (not critical / never) to 5 (very critical / always) were used to enable the respondents to express the criticality and frequency of the identified factors. The score of each component was calculated by summing up the ratings of the relevant items.

Lagos State Polytechnic was used as a preliminary sample to validate the efficacy of the variables before further application in other polytechnics. Lagos State Polytechnic was chosen as acase study for two reasons: (1) the selected school is one of the oldest tertiary institutions in Nigeria; and (2) the school attracts a huge number of students due to its location in Lagos. Due to the age of the institution, it is expected that some of its facilities will be defective which affects the health of users (i.e. staff members and students). The survey was conducted in all 5 of the schools in the institution. Twenty-five current polytechnic students were randomly selected from four different academic levels (i.e. ND1, ND2, HND1 and HND2), as well as 9 academic and 11 non-academic staff from each of the schools. A total of 200 respondents participated in the pilot study survey with $50 \%$, $22.5 \%$ and $27.5 \%$, representing students, teaching and non-teaching staff respectively. Data was collected between 1 December 2014 and 29 January 2015. The random sampling method was used in order to increase the likelihood of participation by building users across the institution.

The data collected was analyzed using SPSS version 22.0. To identify the health factors, the 11 items were analyzed by principal component factor analysis with varimax rotation in the study. Cronbach alpha values were calculated to ensure the internal consistency of each building defect and health factors. Lastly, Pearson correlation, stepwise multiple regression analysis was adopted to investigate the relationships between the building defects and the health factors among the students and members of staff in the Lagos State Polytechnic. 


\section{Result}

\section{Descriptive statistics and reliability analysis of building defects}

From Table 1, water overflow from water closet and undrained toilet floor water (3.00) ranked as the most prominent defects in the school. Damaged water taps, water closet, dampness on the toilet wall, and defacement of walls with posters (2.90) ranked as the second most prominent defects experienced in the institution. These are followed by cobwebs in classrooms and workshops, damaged doors and door frames, faulty design and construction, and fade painted surfaces (2.80). In addition, damaged door locks, ceiling fans, fluorescence, electrical installations, furniture's and fittings, cobwebs in the laboratory, classroom ceiling, pipe leakages and dampness on the classroom wall recorded a mean score of 2.70 respectively. Defects such as cracks on walls, plant growth and algae on the walls and roof, roof covering, undrained water on the road surface and poor landscaping scored a mean between $2.20-2.40$. The significant defects in the institution were damaged window rail and frame, damaged air conditions, poor landscaping, roof covering, furniture's and fittings, water closets and taps, undrained surface water on roads and rough installation of service ducts with significant values of $\mathrm{p}<0.05$ (see Table 1).

To test the internal consistency, reliability analysis was conducted on building defects identified in the study (see Table 1). Nine building defects were identified, including cobwebs (D1), damages to facilities (D2), dampness (D3), plumbing problems (D4), electrical problems (D5), poor design/maintenance of grounds (D6), roofing problems (D7), problems with the walls (D8) and finishes problems (D9). The results show that roofing problems (D7), problems with walls (D8) and poor finishes (D9) were unreliable (i.e., alpha values were less than 0.5), and were therefore not considered significant contributors to the study (Hair et al., 2010). The reasons for the unreliability of the data for D7, D8 and D9 may be due to the difficulty of identifying the defects and their influence on health by the respondents, or related to the size of the sample considered in the study.

\section{Descriptive statistics and factor analysis of health factors}

The health problems experienced in the polytechnic were analysed as shown in Table 2. Heat and discomfort (3.50) is the most critical health issues experienced in the institution. Body pain (2.70) and headache (2.50) ranked as the second and third critical health problems according to the respondents. These three critical health problems in the school are factors grouped under physical health related problems. Furthermore, physiological health issues such as dizziness (2.40), coughs (2.20) and colds (2.20) are less critical health challenges in the polytechnic.

To identify the main health factors, principal component analysis with varimax rotation (Eigen-value: 1 cutoff) was adopted (Pallant, 2011). The suitability of data for factor analysis was considered using the Kaiser-Meyer-Olkin (KMO) value (0.710) which exceeded the recommended value of 0.6 (Tabachnick and Fidell, 2007); while the Bartlett's Test of Sphericity $(\mathrm{p}=0.000)$ is significant (Pallant, 2011). To ensure items were loaded into the same factors, loadings greater than 0.5 were considered valid (Hair et al., 2010). Three factors were generated, namely physiological health (H1), physical health (H2) and psychological health (H3), explaining $66.0 \%$ of the total variance. All the health factors were reliable with Cronbach alpha values higher than 0.5 (see Table 2). 
Table 1: Scale item mean, rank, significance and reliability analysis of defects

\begin{tabular}{|c|c|c|c|c|c|c|}
\hline Factors & Items & Descriptions & Mean & Rank & Sig. & $\alpha$-value \\
\hline \multirow[t]{5}{*}{ D1-Cobwebs and dust } & 1. & Cobwebs in classroom & 2.80 & 7 & 0.41 & 0.656 \\
\hline & 2. & Cobwebs in workshops & 2.80 & 7 & 0.80 & \\
\hline & 3. & Cobwebs in laboratory & 2.70 & 12 & 0.89 & \\
\hline & 4. & Cobwebs in offices & 2.50 & 28 & 0.56 & \\
\hline & 5. & Dust accumulation & 2.60 & 22 & 0.77 & \\
\hline \multirow{8}{*}{$\begin{array}{l}\text { D2-Damages } \\
\text { and fittings }\end{array}$} & 6. & Damaged ceiling in classroom & 2.70 & 12 & 0.09 & 0.832 \\
\hline & 7. & Damaged ceiling in offices & 2.60 & 22 & 0.35 & \\
\hline & 8. & Damaged classroom board & 2.50 & 28 & 0.36 & \\
\hline & 9. & Broken window glaze & 2.60 & 22 & 0.07 & \\
\hline & 10. & Damaged door locks & 2.70 & 12 & 0.26 & \\
\hline & 11. & Damaged windows rail and frame & 2.58 & 27 & $0.04 * *$ & \\
\hline & 12. & Damage door and door frame & 2.80 & 7 & 0.32 & \\
\hline & 13 & Damaged furniture and fittings & 2.70 & 12 & $0.03 * *$ & \\
\hline \multirow[t]{3}{*}{ D3-Dampness problems } & 14. & Dampness on walls in toilet & 2.90 & 3 & 0.59 & 0.636 \\
\hline & 15. & Dampness of classroom walls & 2.70 & 12 & 0.49 & \\
\hline & 16. & Dampness of office walls & 2.50 & 28 & 0.18 & \\
\hline \multirow[t]{5}{*}{ D4-Plumbing problems } & 17. & Damaged water taps & 2.90 & 3 & $0.02^{* *}$ & 0.658 \\
\hline & 18. & Damage water closet & 2.90 & 3 & $0.02 * *$ & \\
\hline & 19. & Overflow of water in the water closet & 3.00 & 1 & 0.13 & \\
\hline & 20. & Undrained toilet floor water & 3.00 & 1 & 0.58 & \\
\hline & 21. & Pipe leakages & 2.70 & 12 & 0.08 & \\
\hline \multirow[t]{5}{*}{ D5-Electrical problems } & 22. & Damaged ceiling fan & 2.70 & 12 & 0.43 & 0.691 \\
\hline & 23. & Faulty electrical installation & 2.70 & 12 & 0.38 & \\
\hline & 24. & Rough connection of air condition duct pipes & 2.60 & 22 & $0.01 * *$ & \\
\hline & 25. & Damaged air condition & 2.66 & 21 & $0.04 * *$ & \\
\hline & 26. & Burnt and damaged fluorescence & 2.70 & 12 & 0.64 & \\
\hline \multirow{3}{*}{$\begin{array}{l}\text { D6-Poor design/ } \\
\text { maintenance }\end{array}$} & 27. & Faulty design, construction and maintenance & 2.80 & 7 & 0.31 & 0.579 \\
\hline & 28. & Poor design/maintenance of landscaping & 2.40 & 31 & $0.05^{* *}$ & \\
\hline & 29 & Undrained water on road/car parks & 2.30 & 33 & $0.01 * *$ & \\
\hline \multirow[t]{2}{*}{ D7-Roofing problems } & 30. & Defect in roof covering & 2.40 & 31 & $0.04 * *$ & 0.366 \\
\hline & 31. & Plant grow and algae on roof top & 2.30 & 33 & 0.39 & \\
\hline \multirow[t]{3}{*}{ D8-Problems with walls } & 32. & Wall cracks & 2.20 & 36 & 0.39 & 0.485 \\
\hline & 33. & Plant grow and algae on wall & 2.30 & 33 & 0.49 & \\
\hline & 34. & Defacement of walls with poster etc. & 2.90 & 3 & 0.31 & \\
\hline \multirow[t]{2}{*}{ D9- Finishes problems } & 35. & Floor finishes deterioration & 2.60 & 22 & 0.39 & 0.215 \\
\hline & 36. & Faded paints & 2.80 & 7 & 0.19 & \\
\hline
\end{tabular}

Significant at $\mathrm{p}<0.05$, Not Critical $=1$ to Very Critical $=5$

Table 2: Scale items,mean, factor loadings and coefficient alpha reliabilities for health factors

\begin{tabular}{|c|c|c|c|c|c|c|c|c|}
\hline Factors & Nature & Items & Descriptions & Mean & Rank & Sig. & $\begin{array}{l}\text { Factor } \\
\text { loading }\end{array}$ & $\begin{array}{c}\alpha- \\
\text { value }\end{array}$ \\
\hline \multirow{5}{*}{$\begin{array}{l}\text { H1-Physiological } \\
\text { health }\end{array}$} & + & 1. & Cough & 2.20 & 5 & 0.51 & 0.782 & \multirow[t]{5}{*}{0.738} \\
\hline & + & 2. & Dizziness & 2.40 & 4 & 0.90 & 0.679 & \\
\hline & + & 3. & Cold & 2.20 & 5 & 0.84 & 0.645 & \\
\hline & + & 4. & Skin irritation & 1.90 & 10 & 0.08 & 0.606 & \\
\hline & + & 5. & Running nose or eyes & 2.20 & 5 & 0.23 & 0.553 & \\
\hline \multirow[t]{4}{*}{ H2-Physical health } & + & 6. & Heat and discomfort & 3.50 & 1 & $0.02^{*}$ & 0.803 & \multirow[t]{4}{*}{0.764} \\
\hline & + & 7. & Body pain & 2.70 & 2 & 0.13 & 0.801 & \\
\hline & + & 8. & Eye pain & 2.00 & 8 & 0.39 & 0.691 & \\
\hline & + & 9. & Headache & 2.50 & 3 & 0.23 & 0.639 & \\
\hline \multirow{2}{*}{$\begin{array}{l}\text { H3-Psychological } \\
\text { health }\end{array}$} & + & 10. & Reduction in memory & 1.70 & 11 & 0.73 & 0.897 & \multirow[t]{2}{*}{0.774} \\
\hline & + & 11. & Mental fatigue & 2.00 & 8 & 0.41 & 0.846 & \\
\hline
\end{tabular}

Significant at $\mathrm{p}<0.05$, Never $=1$ to Always $=5$ 


\section{Correlation analysis between defects and health factors}

Pearson correlation analysis was employed to investigate the relationship between educational building defects and the health problems experienced in the polytechnic. The result of the correlation indicates that there is a positive statistical relationship between physiological health (H1) and cobwebs and dust (D1), damages to joinery/fittings and openings (D2), dampness problems (D3), plumbing problems (D4), electrical problems (D5), and poor design/maintenance of buildings/grounds (D6). The significant level is at $\mathrm{p}<0.01$. In a similar vein, at $\mathrm{p}<0.01$ significant level, a positive correlation exists between physical health (H2) and defects D1 - D6. Also, there is a significant positive relationship between psychological health (H3) and cobwebs and dust (D1, p $<0.01$ ), damage to joinery/fitting and openings (D2, p < 0.05) and dampness problems (D3, p < 0.05). However, there is no significant relationship between psychological health (H3) and plumbing problems (D4), electrical problems (D5) and poor design/maintenance of buildings and grounds (D6) as shown in Table 3.

Table 3: Descriptive statistic and Pearson correlations of defects and health factors

\begin{tabular}{|c|c|c|c|c|c|c|c|c|c|c|c|}
\hline Variables & Mean & S.D & H1 & H2 & H3 & D1 & D2 & D3 & D4 & D5 & D6 \\
\hline H1 - Physiological health & 13.23 & 4.76 & 1.00 & & & & & & & & \\
\hline H2 - Physical health & 13.09 & 4.25 & $.385^{* *}$ & 1.00 & & & & & & & \\
\hline H3 - Psychological health & 3.84 & 2.38 & $.451 * *$ & $.208 * *$ & 1.00 & & & & & & \\
\hline D1 - Cobwebs and dust & 12.56 & 4.73 & $.392^{* *}$ & $.264^{* *}$ & $.299 * *$ & 1.00 & & & & & \\
\hline $\begin{array}{l}\text { D2 - Damages to joinery and } \\
\text { fittings }\end{array}$ & 18.22 & 6.44 & $.275^{* *}$ & $.323^{* *}$ & $.159 *$ & $.512^{* *}$ & 1.00 & & & & \\
\hline D3 - Dampness problems & 13.22 & 5.78 & $.385^{* *}$ & $.352^{* *}$ & $.180^{*}$ & $.570^{* *}$ & $.558^{* *}$ & 1.00 & & & \\
\hline D4 - Plumbing problems & 19.32 & 4.45 & $.353^{* *}$ & $.363^{* *}$ & .065 & $.507^{* *}$ & $.508^{* *}$ & $.523^{* *}$ & 1.00 & & \\
\hline D5 - Electrical problems & 16.33 & 5.90 & $.317^{* *}$ & $.299^{* *}$ & .047 & $.393^{* *}$ & $.329^{* *}$ & $.553^{* *}$ & $.409^{* *}$ & 1.00 & \\
\hline D6 - Poor design/ maintenance & 9.54 & 3.82 & $.237^{* *}$ & $.307^{* *}$ & -.026 & $.493^{* *}$ & $.572^{* *}$ & $.687^{* *}$ & $.501^{* *}$ & $.366^{* *}$ & 1.00 \\
\hline
\end{tabular}

\section{Multiple regression analysis between defects and health factors}

Multiple regression analysis with a stepwise method of analysis was conducted to examine the predictive ability of the building defects on the health of the students and staff members of the institution (Pallant, 2011). As a measure to check for multicollinearity between the dependent and independent variables, the variation inflation factor was explored (see Table 4). The result indicates that the VIF ranged between 1 and 10 suggesting no problem of multicollinearity (Hair et al., 2010).

In the first regression model for physiological health (H1), the result indicates that damaged joinery/fittings and openings (D2) is the predictor which has the highest correlation of 0.361 with physiological health (H1). In addition, D2 explained $13.0 \%$ of the variance in the dependent variable (H1). In step 2 of the model, D2 and D1 explained $16.0 \%$ of the variance in physiological health $(\mathrm{H} 1)$. The $\mathrm{R}$ Square Change $(\Delta \mathrm{R} 2)$ shows that cobwebs and dust (D1) shared an additional $3.0 \%$ of the variance in $\mathrm{H} 1$ as a second predictor. Furthermore, the Beta weights are positive, so there is a positive relationship between damaged joinery/fittings and openings $(\mathrm{D} 2=0.241)$ and cobweb and dust $(\mathrm{D} 1=0.211)$ and physiological health $(\mathrm{H} 1)$. Also, the $\mathrm{t}$ value and Sig. values indicate that the two independent variables (D2 and D1) contribute significantly to the prediction (as shown in Table 4).

The result of the regression model for physical health (H2) shows that electrical problems (D5) have the highest correlation of 0.364 with $\mathrm{H} 2$ as the main predictor. Electrical problems (D5) shared with 
$13.2 \%$ variance of the physical health (H2). In step 2 of the model, electrical problems (D5) and dampness problems (D3) explained 16.6\% of the variance in physical health (H1). The R Square Change $(\Delta \mathrm{R} 2)$ indicates that dampness problems (D3) account for an additional 3.3\% of the variance in physical health $(\mathrm{H} 2)$ as a second predictor. Furthermore, the Beta weights are positive, so there is a positive relationship between electrical problems (D5 $=0.261$ ) and dampness problems $(\mathrm{D} 3=0.210)$ and physical health $(\mathrm{H} 2)$. Also, $\mathrm{t}$ value and their Sig. values indicate that the two independent variables (D5 and D3) contribute significantly to the prediction according to Table 4.

Table 4: Multiple regression analysis model for defects and health

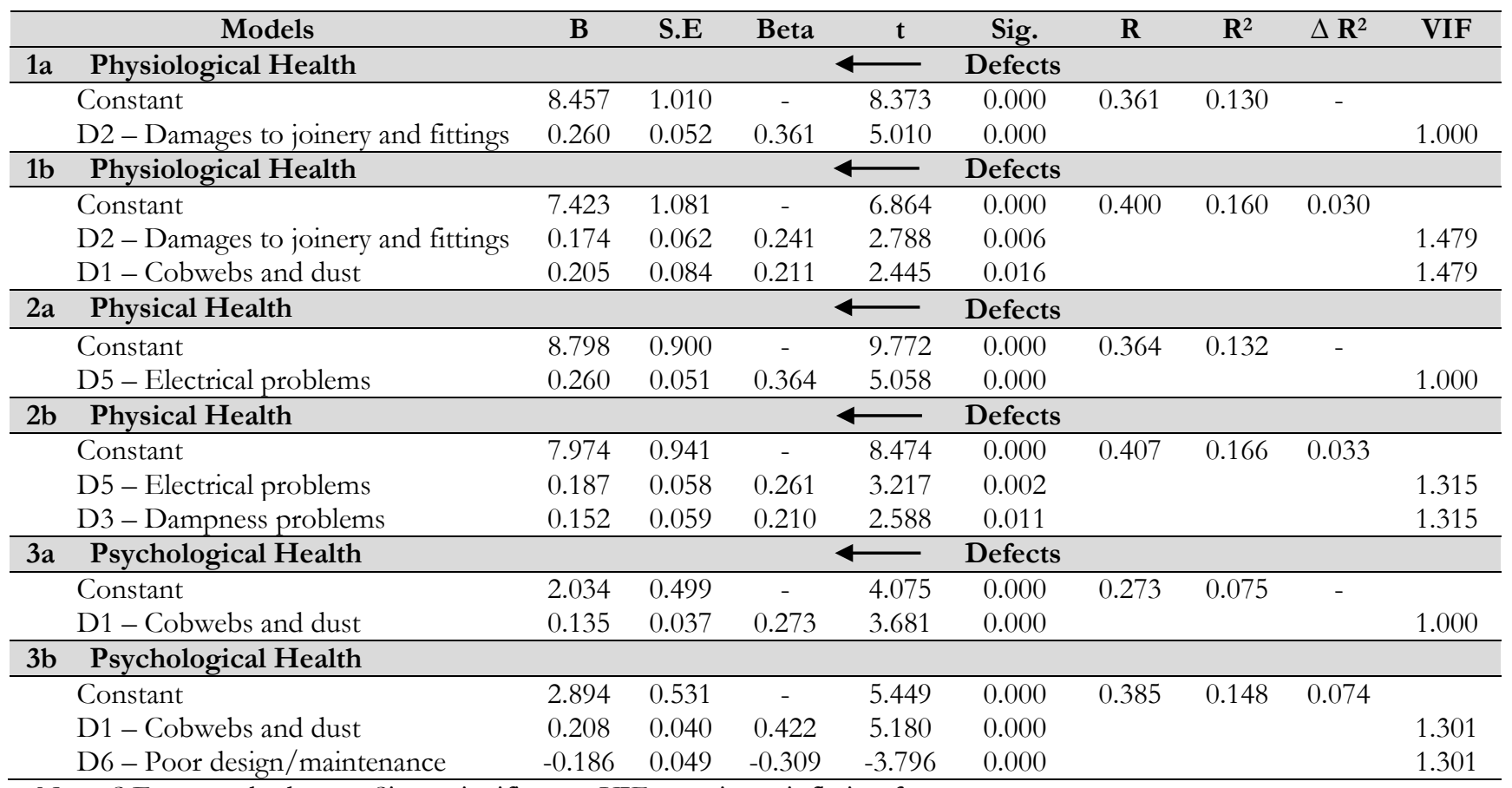

Note: S.E. = standard error; Sig. = significance; VIF = variance inflation factor

The result of the psychological health (H3) regression model indicates that cobweb and dust (D1) is the predictor which has the highest correlation of 0.273 with psychological health (H3). Cobweb and dust (D1) explained a further $7.5 \%$ of the variance in psychological health $(\mathrm{H} 3)$. In step 2 of the model, cobweb and dust (D1) and poor design/maintenance of buildings and grounds (D6) explained $14.8 \%$ of the variance in psychological health $(\mathrm{H} 3)$. The R Square Change $(\Delta \mathrm{R} 2)$ shows that cobwebs and dust (D1) shared an additional 7.4\% of the variance in $\mathrm{H} 3$ as a second predictor. Furthermore, the Beta weight of cobweb and dust $(\mathrm{D} 1=0.422)$ is positive, so there is a positive relationship between cobweb and dust (D1) and psychological health (H3). The beta value for poor design and maintenance of buildings and grounds (D6=.309) is negative, which indicates a negative relationship with psychological health $(\mathrm{H} 3)$. Also, the $t$ value and their Sig. values indicate that the two independent variables (D1 and D6) contribute significantly to the prediction (see Table 4).

\section{Discussion}

This study adds to existing knowledge by providing insights into the influence of building defects on health of users of educational facilities. The present study is the first to report the relationship 
between building conditions and health of users of educational buildings in developing countries in construction-related literature. The findings indicate that a relationship exists between building condition and the health of users. Furthermore, the result of the correlation indicates that a significant positive relationship exists between physiological and physical health, and building defects such as cobwebs and dust (D1), damaged joinery/fittings and openings (D2), dampness problems (D3), plumbing problems (D4), electrical problems (D5) and poor design/maintenance of buildings and grounds (D6). While a significant positive relationship exists between psychological health and cobwebs and dust (D1), damaged joinery/fitting and openings (D2) and dampness problems (D3). Furthermore, there is no significant relationship between psychological health and plumbing (D4) and electrical (D5) problems, and poor design/maintenance of buildings and grounds (D6).

The results of the multiple regression analysis indicate that the building condition has a predictive ability on the health of students and staff. The physiological health (H1) is predicted by damaged joinery/fittings and openings (D2) and cobwebs and dust (D1). Physical health (H2) is predicted by electrical problem (D5) and dampness problem (D3), while psychological health is a prediction of cobweb and dust (D1) and poor design/maintenance of buildings and grounds (D6).

The findings of this study indicate that plumbing problems can cause eye irritation, respiratory infection and nasal congestion, which support the findings of Claudio, Rivera and Ramirez (2016). In educational institutions, the numbers of users utilizing the plumbing installations for daily life activities are large and diverse. Due to the rate of usage, damage to taps are a common occurrence in the polytechnic. In Nigeria, the level of care for public facilities is very low, which often necessitates the need to change them frequently. However, due to a poor maintenance culture, facilities are often left to degenerate beyond repair and even abandoned for a long time before they are scheduled for change. Water supply from the damaged taps may have been contaminated, which sometimes may lead to skin and eye irritation and itching among students when used in rest rooms. In fact, the overflow of water in the water closet or undrained toilet floor water can cause students to fall when using the toilet, which can result in body pain and headache.

Damaged joinery/fittings and openings (D2) caused adverse health problems due to the fact that the features (doors, windows, ceiling etc.) cannot function effectively. The failure of these components exposes the indoor environment to external environmental hazards like dust, and water ingress which induces health hazards in occupants. Physiological health $(\mathrm{H} 1)$ experienced such as cough, dizziness, cold, and running nose or eyes can be as a result of the presence of dust in the indoor environment. This is in accordance with Claudio et al., (2016) finding that dust induces cold, nasal congestion, and sore throat in occupants. Dust also induced psychological health hazards in occupants. The result also support the statement that students psychosocial factors were associated with indoor air quality (Finell et al., 2016).

The results of the study also show that electrical problems affect the physical health of students and staff members. Due to the intensity of use of electricity and lighting in the academic setting, fluorescent bulbs reach their useful shelf-life faster and cause the fluorescent to become damaged in a short time. The situation becomes worse when the light remains switched on permanently even when not in use. In fact, faulty electrical installation can trigger damage to air conditioning, fluorescent lighting and ceiling fans. Damaged mechanical ventilation systems make the indoor areas uncomfortable for users (i.e. student and academic staff) due to heat and a high concentration of carbon dioxide. This could be responsible for the eye pain and headaches experienced by users. These results appear to be consistent with those of previous studies (Wong and Jan, 2006; Amina et 
al., 2015; Takaokai et al., 2016) which indicate that SBS are associated with air humidity and thermal comfort in indoor environments.

Dampness problems influence the physical health experienced in the institution. Singh et al. (2010) and Putus (2012), acknowledged that poor design, construction and maintenance are common causes of dampness/moisture problems. The dampness of the walls of buildings results in unacceptable internal environmental conditions (Singh et al., 2010). Dampness supports mold, plant and algae growth in buildings, which produce toxins that are harmful to human health (Putus, 2012; Singh et al., 2010; Wong and Jan, 2006). Dampness problems cause non-respiratory symptoms like body pains and headaches (Putus, 2012) as indicated in the result of the study. Due to seasonal variation and flooding in the study area, the quantity of moisture within the lower parts of buildings increases causing dampness to the building. The dampness on the walls of the buildings results in unacceptable internal environmental conditions (Briffet 1994). In fact, an increase in the moisture content of buildings can also result in physiological health problems such as skin and eye irritation, cold, respiration infections and running nose (Putus, 2012; Claudio et al., 2016).

The study findings also reveal that cobwebs affect psychological health. Cobwebs (produced by spiders) are common occurrences in building structures within the institution. In the south-west of Nigeria (within which the case institution is located), it is culturally believed that cobwebs bring illluck. This may be responsible for some psychological feelings experienced by users. In addition, poor design and maintenance contributes to psychological health experienced in the polytechnic, because dysfunctional facilities induce phobias and a reduced sense of safety and security in users.

The results of the study have added valuable knowledge to literature on facilities and its impact on the health of users. It was found that it is necessary for construction professionals in the physical planning department to ensure functional facilities within the polytechnic. This will improve the health of the students and staff and their academic performance. The scarcity of resources which stems from dwindling prices in the commodity markets necessitates a need for prioritizing maintenance works in Nigeria. The findings of the present study provide stakeholders with information on critical facilities in educational buildings which have adverse effects on the health of users (i.e. students and academic staff). This information could be useful in developing and implementing strategic building maintenance policies for academic institutions in Nigeria and other similar developing countries.

\section{Conclusion}

In recent years, there has been a concerted effort targeted at improving the indoor environment due to its impact on the health of occupants. This study set out to determine the relationship between educational building defects and health of users (i.e. students and staff members) in a polytechnic located in Nigeria. The present study is a preliminary investigation, which forms the basis for a larger study covering tertiary educational institutions in Nigeria. Nine groups of defects in educational buildings were identified in the study, which include cobwebs and dust, damages to joinery/fittings and openings, dampness problems, plumbing problems, electrical problems, poor design/maintenance of buildings and grounds, roofing problems, problems with walls, and finishes problems. In addition, the health problems experienced in the institution are classified under three health groups, namely physiological, physical and psychological health.

The study revealed that plumbing problems, dampness, defacement of walls, cobwebs and dust, damages to joinery/ fittings and openings are prominent defects in the institutional buildings. In the same vein, heat and discomfort, body pain and headaches were identified as significant health 
problems experienced by users. The results of the study also established that there is a significant statistical relationship between building defects and the health of students and staff. However, no significant relationship between psychological health and plumbing and electrical problems, and poor design/maintenance of grounds was found. Furthermore, damaged joinery/fittings and openings is the main predictor of physiological health. Physical health is mostly influenced by electrical problems, while cobweb and dust show the highest correlation with psychological health. This necessitates the need for a proactive approach to facilities maintenance management in educational institutions so that educational facilities can function effectively to improve performance and health of both the students and staff.

Although the results of the present study suggest a relationship between building defects and health of users (i.e. staff members and students), the use of self-reported surveys raises questions about subjectivity of perception. Certain measures were put in place however to reduce the possibility of bias. Firstly, the study employed the use of personal observation and interview of users for identifying the building defects. Secondly, the identified scales for measurement were tested for reliability with Cronbach alpha values greater than 0.5 (Hair,et al., 2010). Thirdly, users of the building (i.e. registered students and staff members) of the polytechnic were randomly selected for participation in the pilot study. Fourthly, all the respondents have spent at least close to one year in the polytechnic, which may indicate their knowledge of defects in the buildings and the health risks they experienced while using the buildings and its ancillary services. Though, there are other influencing factors such as domestic exposure (see Van Dijken et al., 2006) that affect the health of the students and which were not considered in this study. The use of the four measures stated earlier ensures that inferences drawn from the results of the study are reliable and robust.

It should be noted that the current study is based on the perception of the occupants. Hence, there is a need for further studies that will investigate this relationship using alternative methodologies, such as physical experiments, numerical models, or longitudinal observation of building occupants.

\section{References}

Adewunmi, Y., Omirin, M., Famuyiwa, F. and Farinloye, O. (2011) Post-occupancy evaluation of postgraduate hostel facilities.Facilities, 29(3), p.149-168. doi: https://doi.org/10.1108/02632771111109270

Agyekum, K., Ayarkwa, J., Koranteng, C., and Adinyira, E. (2013) Preliminary assessment of dampness in walls of residential buildings in four climatic zones in Ghana.Journal of Sustainable Development, 6(9), p.51-61. doi: https://doi.org/10.5539/jsd.v6n9p51

Al-Sehaimi, A., Koskela, L. and Tzortzopoulos, P. (2013) Need for alternative research approaches in construction management: case of delay studies. Journal of Management in Engineering, 29(4), p.407-413. doi: https://doi.org/10.1061/(ASCE)ME.1943-5479.0000148

Amina, N.D.M, Akasahb, Z.A., and Razzalyc, W. (2015) Architectural evaluation of thermal comfort: sick building syndrome symptoms in engineering education laboratories. Procedia - Social and Behavioral Sciences, 204, p.19-28. doi: https://doi.org/10.1016/j.sbspro.2015.08.105

Boussabaine, A. H. and Kirkham, R. J. (2004) Simulation of maintenance costs in UK local authority sport centres. Construction Management and Economics, 22(10), p.1011-1020. doi: https://doi.org/10.1080/01446190410001678107

Briffett, C. (1994) Building Maintenance Technology in Tropical Climate: Investigating Dampness Problem in Buildings. Singapore: Singapore University Press.

Chan, D. D. W. and Hung, H. T. (2015) An empirical survey of the perceived benefits of implementing the Mandatory Building Inspection Scheme (MBIS) in Hong Kong.Facilities, 33(5/6), p.337-366. doi: https://doi.org/10.1108/F-09-2013-0066 
Chang, T. I. and Tamura, M. K. (2009) Methods to assess quality of life and functional status and their applications in clinical care in elderly patients with CKD.American Society of Nephrology. [online] Available at: $<$ https://www.asnonline.org/education/distancelearning/curricula/geriatrics/Chapter35.pdf $>$ ( Accessed September 4 2014).

Chiang, Y. H., Li, J., Zhou, L., Wong, F. K. and Lam, P. T. (2014) The nexus among employment opportunities, lifecycle costs, and carbon emissions: a case study of sustainable building maintenance in Hong Kong. Journal of Cleaner Production, 109, p.326-335. doi: https://doi.org/10.1016/j.jclepro.2014.07.069

Claudio, L. Rivera, G.A., and Ramirez, O.F. (2016) Association between markers of classroom environmental conditions and teachers' respiratory health.Journal of School Health, 86(6), p.444-451. doi: https://doi.org/10.1111/josh.12398

Cummins, R. A. (1997) Comprehensive quality of life scale: adult (5th bed. (ComQol-A5). [online] Available at:<http://www.deakin.edu.au/research/acqol/instruments/comqol-scale/comqol-a5.pdf $>$ ( Accessed May 7, 2014)

Escuder-Mollon, P., Clemente-Esteban, R. A., Flores-Buils, R. and Esteller-Curto, R. (2012) Evaluation toolkit on seniors education to improve their quality of life - LLP QEduSen Project. [online] Available at $<\mathrm{http://www.edusenior.eu>}$ (Accessed June 13 2014).

Falorca, J., Rodrigues, R. C. and Da Silva, R. M. (2014) Research measurement of knowledge advances in building maintenance issues. Structural Survey, 32(1), p.61-71. doi: https://doi.org/10.1108/SS-08-2012-0023

Finell, E., Haverinen-Shaughnessy, U., Tolvanen, A., Laaksonen, S., Karvonen, S., Sund, R., Saaristo, V., Luopa, P., Stahl, T., Putus, T., and Pekkanen, J. (2016) The associations of indoor environment and psychosocial factors on the subjective evaluation of indoor air quality among lower secondary school students: a multilevel analysis. Indoor Air, p.1-9. doi https://doi.org/10.1111/ina.12303

Forcada, N., Macarulla, M., Gangolells, M. and Casals, M. (2015) Handover defects: comparison of construction and post-handover housing defects. Building Research and Information, (in press), doi: https://doi.org/10.1080/09613218.2015.1039284.

Gomez, M. M. N., Gitierrez, R. M. V., Castellamos, S. A. O., Vergara, M. P. and Pradilla, Y. K. R., 2010.Psychologial well-being and quality of life in patients treated for thyroid cancer after surgery. Psychological Therapy, 28(1), p.69-84. doi: https://doi.org/10.4067/S0718-48082010000100007

Gou, Z. and Lau S. S. Y. (2012) Sick building syndrome in open-plan offices.Journal of Facilities Management, 10(4), p.256265.doi: https://doi.org/10.1108/14725961211265729

Gupta, R. and Chandiwala, S. (2010) Understanding occupants:feedback techniques for large-scale low-carbon domestic refurbishments, Building Research \& Information, 38:5, 530-548, doi: https://doi.org/10.1080/09613218.2010.495216

Gupta, R. and Kapsali, M. (2016) Evaluating the 'as-built' performance of an eco-housing development in the UK. Building Serv. Eng. Res. Technol. 0(0) p.1-23 doi: https://doi.org/10.1177/0143624416629404

Gupta, S., Khare, M., Goyal, R., (2007) Sick building syndrome: A case study in a multistorycentrallyair-conditioned building in the Delhi City.Building and Environment 42, p.2797-2809. doi: https://doi.org/10.1016/j.buildenv.2006.10.013

Hair, J. F., Black, W. C., Babin, B. J. and Anderson, R. E., (2010) Multivariate data analysis (7th ed.). Upper Saddle River, NJ: Pearson Education.

Hassanain, M. A. (2008) On the performance evaluation of sustainable student housing facilities.Journal of Facilities Management, 6(3), p.212-225. doi: https://doi.org/10.1108/14725960810885989

Hassanain, M.A., andMudhei, A.A. (2006) Post-occupancy evaluation of academic and research library facilities, Structural Survey, 24 (3), p.230 - 239. doi: https://doi.org/10.1108/02630800610678878

Hasselaar, E. (2009) Health issues and the building stock.Building Research and Information, 37(5/6), p.669-678, https://doi.org/10.1080/09613210903186836.

Kok, H. B., Mobach, M. P. and Omta, S. W. F. (2011) The added value of facility management in the educational environment. Journal of Facilities Management, 9(4), p.249-265. doi:

https://doi.org/10.1108/14725961111170662

Lavy, S., (2008). Facility management practice in higher education buildings: a case study. Journal of Facilities Management, 6(4), p. 303-315. doi: https://doi.org/10.1108/14725960810908163

Leung M. Y. and Fung, I. (2005) Enhancement of classroom facilities of primary schools and its impact on learning behaviors of students.Facilities 23(13/14), p.585-594. doi: https://doi.org/10.1108/02632770510627561

Low, P. S. and Darren, W. (2001) Improving maintenance and reducing building defects through ISO 9000. Journal of Quality in Maintenance Engineering, 7(1), p.6-24. doi: https://doi.org/10.1108/13552510110386865 
McGrath, P. T. and Horton, M. (2011) A post-occupancy evaluation (POE) study of student accommodation in an MMC/modular building. Structural Survey, 29(3), p.244-252. doi: https://doi.org/10.1108/02630801111148211

Olanrewaju, A. A. (2012) Quantitative analysis of defects in university buildings: user perspective. Built Environment Project and Asset Management, 2(2), p.167-181. doi: https://doi.org/10.1108/20441241211280909

Pallant, J. (2011) SPSS survival manual: a step by step guide to data analysis using SPSS (4th ed.). China: Everbest Printing Company.

Putus, T. (2012) Indoor air problems - exposure and bealth effects. [online] Available at: <http://www.helsinki.fi/henvi/yvv/esitykset/Putus2012.pdf> (Accessed 10 January 2016)

Salleh, N.M, Salim, N.A.A, Kamaruzzaman, S.N., Mahyuddin, N., and Darus, F.M. (2016) The prevelence of SBS and absenteeism among children in urban refurbished private pre-schools. MATEC Web of Conferences, 66, p.1-12. doi: https://doi.org/10.1051/matecconf/20166600119

Sawyerr, P. T. and Yusof, N. (2013) Student satisfaction with hostel facilities in Nigerian polytechnics.Journal of Facilities Management, 11(4), p.306-322, doi: https://doi.org/10.1108/JFM-08-2012-0041.

Schalock, R. L. and Verdugo, M. A. (2002) Handbook on quality of life for human service practitioners. Washington, DC: American Association on Mental Retardation.

Shohet, I. M. and Paciuk, M. (2006) Service life prediction of exterior cladding components under failure conditions.Construction Management and Economics, 24(2), p.131-148. doi: https://doi.org/10.1080/01446190500184535

Simpeh, F. (2013) Current maintenance strategies of university building facilities in the Western Cape, South Africa (Unpublished master thesis). Cape Peninsula University of Technology, South Africa.

Singh, J., Yu, C.W.F., and Jeong Tai Kim, J.T. (2010) Building pathology, investigation of sick buildings toxic moulds.Indoor Built Environ, 19(1). p.40-47. doi: https://doi.org/10.1177/1420326X09358808

Sivam, A. and Karuppannan, S. (2015) Factor influencing old age persons' residential satisfaction: a case study of South Australia. Refereed paper submitted for the Re-imagining Sociology Conference, Thammasat University, Bangkok, Thailand, 15-17 July 2015.

Starfield, B. (2001) Basic concepts in population health and health care. Journal of Epidemiology and Community Health, 55, p.452-454. doi: https://doi.org/10.1136/jech.55.7.452

Tabachnick, B. G. and Fidell, L. S. (2007) Using multivariate statistics (5th ed.) Boston: Pearson Education.

Takaokai, M., Suzuki, K., and Norbäck, D. (2016) Sick building syndrome among junior high school students in Japanin relation to the home and school environment. Global Journal of Health Science; 8(2), p.165-177. doi: https://doi.org/10.5539/gjhs.v8n2p165

Tanner, C. K. (2000) The influence of school architecture on academic achievement.Journal of Educational Administration, 38(4), p.309-330.doi: https://doi.org/10.1108/09578230010373598

Tanner, C. K. (2009) Effects of school design on student outcomes. Journal of Educational Administration, 47(3), p.381-399. doi: https://doi.org/10.1108/09578230910955809

Thietart, R. A. (2001) Doing management research: a comprehensive guide. Sage Publications: London. doi: https://doi.org/10.4135/9781849208970

Uline, C. and Tschannen-Moran, M. (2008) The walls speak: the interplay of quality facilities, school climate, and student achievement. Journal of Educational Administration, 46(1), p.55-73. doi: https://doi.org/10.1108/09578230810849817

Vafaeenasab, M.R, Morowatisharifabad, M. A, Ghaneian, M.T, Hajhosseini, M., and Ehrampoush, M.H. (2015) Assessment of sick building syndrome and its associating factors among nurses in the educational hospitals of ShahidSadoughi University of Medical Sciences, Yazd, Iran. Glob J Health Sci. 7(2), p.247-253. doi: https://doi.org/10.5539/gjhs.v7n2p247

Van Dijken, F., Van Bronswijk, J. E. M. H. and Sundell, J. (2006) Indoor environment and pupils' health in primary schools.Building Research and Information, 34(5), p.437-446. doi: https://doi.org/10.1080/09613210600735851

Wahab, S. N. A. and Hamid, M. Y. (2011) A review factors affecting building defects of structural steel construction. case study: student accommodation in UiTMPerak. Procedia Engineering, 20, p.174-179. doi:

https://doi.org/10.1016/i.proeng.2011.11.153

Wing, C. K., Raftery, J. and Walker, A. (1998) The baby and the bathwater: research methods in construction management. Construction Management and Economics, 16(1), p.99-104. doi: https://doi.org/10.1080/014461998372637 
Wong, N. H. and Jan, W. L. S. (2003) Total building performance evaluation of academic institution in Singapore. Building and Environment, 38, p.161-176. doi: https://doi.org/10.1016/S0360-1323(02)00021-5 